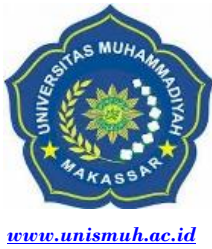

www.unismuh.ac.id
Jurnal Equilibrium Pendidikan Sosiologi

Vol V Mei No. 12017

\title{
Nilai dan Peranan Sosial Perempuan Bali Di Kota Baubau
}

\author{
Rosmawati \\ Universitas Muhammadiyah Butong \\ cumank_uhuy@yahoo.co.id
}

\begin{abstract}
Each family member has a role in a family unit, including wives who have a central role in domestic territory but also sometimes work in the public domain. Technique of data collection is done by using observation, interview, and documentation. Data analysis technique used in this research is using qualitative descriptive analysis. The results showed that culture and belief in religious teachings is one of the factors behind the formation of work ethic of Balinese women in living their lives. Activity work is based on the belief in Karmapala's law which is believed to be a form of karma from the results of good and bad deeds that bring a high adherence attitude to the planting of virtue values in every act that is born through sincere devotion and sacrifice. To that end, Balinese women always attach great importance to good relations in their every action, hard work, willing to work hard, to sacrifice to slave workers only to achieve a better life later through the process of rebirth (Rengkarnasi) as a measure of deeds of every deed.
\end{abstract}

Keywords: Value, Role, Bali Women

\begin{abstract}
Abstrak. Setiap anggota keluarga memiliki peran dalam suatu unit keluarga, termasuk istri yang memiliki peran sentral dalam wilayah domestik namun juga terkadang bekerja di wilayah publik. Teknik pengumpulan data dilakukan dengan menggunakan observasi, wawancara, dan dokumentasi. Teknik analisis data yang digunakan dalam penelitian ini adalah menggunakan analisis deskriptif kualitatif. Hasil penelitian menunjukan bahwa budaya dan keyakinan akan ajaran agama adalah salah satu faktor yang melatar belakangi pembentukan etos kerja perempuan Bali dalam menjalani kehidupannya. Aktivitas bekerja dilandasi oleh kepercayaan akan hukum Karmapala yang diyakini sebagai bentuk karma dari hasil perbuatan baik maupun buruk yang membawa sikap kepatuhan yang tinggi akan penanaman nilai-nilai kebajikan dalam setiap tindakan yang terlahirkan melalui pengabdian dan pengorbanan yang tulus. Untuk itu, perempuan Bali selalu mementingkan hubungan yang baik dalam setiap tindakannya, kerja keras, rela bekerja keras membanting tulang, berkorban menjadi budak pekerja hanya demi mencapai kehidupan yang lebih baik nantinya melalui proses pelahiran kembali (Rengkarnasi) sebagai ukuran amalan dari setiap perbuatan.
\end{abstract}

Kata Kunci: Nilai, Peranan, Perempuan Bali 


\section{PENDAHULUAN}

Keberadaan

perempuan

dalam

mengaktualisasikan dirinya selalu terkait dengan norma dan nilai yang mengikat setiap gerak-gerik dan sudut pandang tindakan perempuan. Bahkan keinginan bekerja, meniti karir, melanjutkan studi sampai jenjang yang lebih tinggi dan lain sebagainya menjadi keinginan perempuan di samping itu, ia juga ingin menjadi istri shalihah, taat pada suami, menghormatinya dan ingin memberi yang terbaik kepadanya. Selain itu pula, ia ingin menjadi ibu yang terbaik bagi anak-anaknya dan menghantarkan mereka menjadi anak-anak yang shaleh, sukses di dunia dan akhirat. Pada intinya, ia hendak menjadi seseorang yang berhasil untuk diri dan keluarganya secara seimbang tanpa ada yang diprioritaskan. Perempuan adalah mahluk yang unik karena dibalik kelemah lembutannya ternyata perempuan mampu menjadi "super women" dikehidupannya yang memiliki rasa, kesabaran, keuletan, dan kegigihan dalam menjalani kehidupan. Perempuan Bali pertama kali datang ke kota Baubau melalui program transmigrasi pada tahun 1976 sebagai tenaga percontohan dibidang pertanian

Perempuan Bali yang menjalani kehidupannya di kota Baubau tidak saja berperan menjadi Ibu RT tetapi juga bekerja membantu suami mencari nafkah tambahan. Selain itu, rutinitas melayani budaya dan agama dalam hal menyiapkan sajian Yadya adalah salah satu aktivitas yang dijalani tanpa henti. Sifat kerja keras yang perempuan Bali miliki disebabkan oleh semangat hidup untuk berkarya dan mengapdi pada keluarga, budaya, dan leluhur baik melalui nilai-nilai filosofi hidup maupun oleh anjuran agama yang diwujudkan kedalam sikap yang didasari oleh nilai dan norma yang melatar belakangi "etos kerja". Tuntutan akan hidup yang lebih baik membawa perempuan Bali ke problem pengelolaan waktu yang hampir semuanya digunakan untuk pengapdian dalam kehidupannya, baik dalam menjalankan ritual agama, budaya, upacara leluhur, maupun aktivitas keluarga. Sumbangsih perempuan Bali tidak hanya berhenti disitu saja tetapi perempuan Bali dituntut untuk lebih berperan dalam pencarian kebutuhan lainnya yang terkait dengan pendapatan ekonomi keluarga dan pola pengasuhan terhadap anak-anaknya. Hal yang menarik lainnya, kondisi perempuan Bali yang selalu bekerja dan terus bekerja tanpa menghiraukan keadaanya, seolah acuh dengan penampilannya sebagai seorang perempuan dan bahkan mereka nampak tak terurus (kering dan kusam) bahkan lebih tua dari usianya. Kerja keras yg mereka lakoni membawa perempuan Bali dikota Baubau jauh dari "keayuan" sebagai seorang perempuan.

\section{METODE PENELITIAN}

Penelitian ini merupakan jenis penelitian kualitatif yang bertujuan memahami realitas sosial yaitu melihat subjek penelitian dari apa adanya, bukan dari yang seharusnya. Informan ditentukan secara purposive sampling, dimana pemilihan informan dipilih berdasarkan ketentuan bahwa informan tersebut adalah yang melakukan, mengetahui dan memahami persis masalah yang dikaji. Dengan kriteria tokoh agama (pak pendeta), tokoh pendidikan dan pedagang serta beberapa masyarakat biasa maka dalam hal ini, peneliti menentukan informan sebanyak 15 informan. Instrumen dalam penelitian ini adalah peneliti sendiri sebagai pengamat dan pewawancara. Sedangkan dalam mendukung tercapainya hasil penelitian digunakan alat bantu berupa pedoman wawancara, dokumentasi, kamera dan pencatatan hasil penelitian. Teknik pengumpulan data yang digunakan yaitu observasi langsung, wawancara, dokumentasi. Analisis data pada penelitian ini dilakukan secara kualitatif yaitu dari data yang diperoleh kemudian disusun secara sistematis kemudian dianalisa secara kualitatif untuk mencapai kejelasan masalah yang dibahas. Teknik keabsahan data menggunakan teknik triangulasi.

\section{PEMBAHASAN}

1. Kehidupan Sosial Perempuan Bali Terkait dengan Etos Kerjanya di Kota Baubau

a. Aspek Kehidupan Ekonomi. Dalam menunjang aktivitas perekonomian perempuan Bali banyak melakukan pekerjaan salah satunya dengan 
berdagang yang menuntut sifat ulet, kerja keras, dan pengabdian yg tinggi untuk mengembangkan usahanya dengan sangat memperhatikan nilai-nilai ajaran Tat Wam Asih yg mengajarkan kejujuran dalam berdagang.

b. Aspek Kehidupan Sosial. Kebiasaan bekerja bagi perempuan Bali pada umumnya memang sudah menjadi kebiasaan dan bahkan menjadi sebuah tradisi. Dimana mereka selalu diajarkan untuk saling membantu dan memperhatikan orangorang yang ada disekelilingnya melalui pemberian sumbangan terkadang sebagai wadah interaksi dan partisipasi agar perempuan Bali dan masyarakat sekitar saling mengerti satu sama lain.

c. Aspek Kehidupan Adat dan Agama. Aspek kehidupan adat dan agama cukup banyak mengikat tatakelakuan dan partisipasi perempuan Bali sehingga membawa pengaruh dalam berprilaku yg menuntut kedisiplinan dalam setiap sendi kehidupan. Hal inilah yg menjadi titik kunci mengapa perempuan Bali begitu taat menjalankan tradisi dan ritual keagamaan yg memberikan kontribusi pada aspek etos kerjanya.

d. Aspek Kehidupan Berkesenian. Berkesenia bagian dari kehidupan yg diaplikasikan dari nilainilai keindahan terhadap sajian yg terlihat dari berbagai bentuk persembahan yg diasiapkan dalam upacara keagamaan. Keuletan perempuan Bali membuat untaian janur membuktikan bahwa nilai kesenian dalam kehidupan mereka benar-benar tinggi.

e. Aspek Penyaluran Kreativitas, Hoby, dan Waktu Luang. Penyaluran kreativitas, hoby dan waktu luang selalu dipergunakan sebaik mungkin dan kebanyakan diisi dengan bekerja sebagai kegiatan utama. Perempuan Bali terkesan tidak waktu untuk duduk bersantai sambil bergosip atau sekeder mencari kutu di depan rumah. Mereka banyak menghabiskan dengan bekerja, bekerja dan terus bekerja.

2. Peranan Perempuan Bali dalam Keluarga

a. Pola Pengasuhan Perempuan Bali dalam Kelurganya. Perempuan Bali sangat mengutamakan pendidikan budi pekerti, nilai- nilai agama yg teraplikasikan dalam tindakannya, tak lupa kebiasaan untuk bekerja dan membantu orang tua harus ditanamkan sedini mungkin agar anak menjadi orang yang bertanggung jawab dikehidupannya kelak.

b. Tanggung Jawab Perempuan Bali dalam Keluarga. Tanggung jawab perempuan Bali dalam keluarga selalu diperankan sebaik mungkin karena kebiasaan mengurusi keluarga sudah menjadi keharusan dan merupakan bagian dari perbuatan Karmapala. Dalam hal ini bentuk perbuatan yang dilakukan tidak hanya pada kewajiban semata tetapi ada nilai-nilai yang mengikat tatakelakuannya agar selalu berpedoman

c. Kesetiaan Bekerja. Kesetiaan dalam bekerja merupakan rutinitas yang dijalani perempuan Bali dalam kehidupannya dengan rasa tulus iklas membantu suami dalam mencari nafkah. Dalam hal ini semua kewajiban nya dilaksanakan dengan penuh tanggung jawab baik dari jenis pekerjaan yg ringan sampai berat dan semuanya dilakoni dengan sabar.

d. Kepatuhan terhadap Suami. Kesetiaan dan kepatuhan terhadap suami adalah bentuk dari usahanya untuk memberi yang terbaik dalam keluarga, nilai-nilai kepatuhan didasari pada kepercayaan Rengkarnasi (pelahiran kembali) yg berkaitan tentang amalan dikehidupan sebelumnya. Hal inilah yg melatar belakangi mengapa perempuan Bali begitu patuh dan setia terhadap suami sampai dia mampu mengapdi denga tulus iklas tanpa ada rasa lelah sedikitpun

3. Pengaruh Keberadaan Perempuan Bali di Kota Baubau

a. Aktivitas Ekonomi. Kegiatan ekonomi dilihat pada aktivitas berusaha di kota Baubau dapat berjalan dengan baik, hubungan ini mempengaruhi perempuan Buton (masyarakat pribumi) untuk lebih berusaha dalam mencari nafkah. Kegigihan dan kejujuran dalam berusaha yg diperlihatkan perempuan Bali membawa pengaruh positif untuk perempuan Buton yang ikut berdagang dan mengembangkan usahanya. Hilangnya rasa gengsi di perempuan Buton dalam berdagang dan mau ikut serta untuk 
bersama-sama berjualan dilantai dan menjalani aktivitas bersama membuat hubungan mereka lebih akrab sehingga memudahkan mereka untuk bergaul dan membantu satu sama lainnya

b. Aktivitas Sosial. Keberadaan perempuan Bali dikota Baubau yang menjalin hubungan kerjasama dibidang perdagangan mampu mempengaruhi kebiasaan perempuan Buton dalam bersikap jujur, tulus, sopan,lembut dan baik mengingat watak dan prilaku perempuan Buton yg lebih terkesan kasar dan ceplas-ceplos kalau berkomunikasi. Tetapi sejak ada perempuan Bali yg berdagang dikota Baubau dan menjalin hubungan yg intens, perempuan Buton sedikit demi sedikit mulai berubah lebih sopan baik dari tutur katanya sampai pada sikapnya. Selain itu perempuan Bali juga sering berbagi informasi dan keahlian bertani pada perempuan Buton.

Max Weber melihat dunia sebagaimana yang kita saksikan terwujud karena tindakan sosial. Manusia melakukan sesuatu karena mereka memutuskan untuk melakukan itu, untuk mencapai apa yang mereka kehendaki. Bagi Weber struktur sosial adalah produk (hasil) dari tindakan itu, cara hidup adalah produk dari pilihan yang dimotivasi. Memahami realitas sosial yang dihasilkan oleh tindakan itu berarti menjelaskan mengapa menentukan pilihan agar dapat menemukan pemahaman (vestehen) agar individu dapat memahami alasan melakukan tindakan tersebut. Dalam hal ini, etos kerja yang dimiliki oleh perempuan Bali seyogiaya dijadikan alasan untuk menjalankan tradisi turun temurun dalam kehidupan mereka. Alasan bekerja ditujukan untuk penghargaan pada tradisi (budaya) yang mengikat tatakelakuan perempuan Bali sehingga terlahir kebiasaan mengapdi baik dalam kehidupan seharihari, dalam keluarga, maupun pada aktivitas keagamaan yang difungsikan sebagai sarana untuk menopang keyakinan akan kehidupan yang lebih baik nantinya (Rengkarnasi). Kepercayaan ini sudah menjadi pemahaman (vestehen) dalam kehidupan mereka sehingga perempuan Bali dalam bertindak selalu dilatar belakangi rasa cinta kasih terhadap sesama baik ketika menjalin hubungan dengan manusia, hewan maupun tumbuhan.

Proses Rengkarnasi diyakini sebagai sumber motivasi yang terlahirkan dalam sebuah tindakan Rasional terkait dengan etos kerjanya dan pengapdiannya dalam keluarga semata-mata dilakukan untuk mencapai tujuan yang diinginkan yaitu kehidupan yang lebih baik, lebih baik, dan lebih baik sampai dia melampaui yang lebih baik dari yang terbaik dan mencapai Moksa (pembebasan yang abadi) dari perjalanan panjang kehidupannya yang dipenuhi oleh berbagai aturan yang dipatuhi dalam konteks hukum Karmapala, dimana dinyakini sebagai larangan untuk berbuat ingkar pada agama, karena semakin mengikari hukum karmapala berati semakin jauh pada kebaikan yang membawa perempuan Bali pada esensi kehidupan itu sendiri yaitu pencapaian Moksa sehingga perempuan Bali rela melakukan apapun dengan cara bekerja keras dan membanting tulang dalam bertindak untuk mencapai tujuannya. Tindakan Rasional tersebut semata-mata dilatar belakang oleh motivasi untuk mengejar tujuan hidupnya yang membawa pengaruh pada etos kerja dan pengambilan keuntungan dalam berusaha di kota Baubau yang oleh Max Weber mengemukakan lima ciri pokok yang menjadi alasan dalam bertindak yaitu : (a) Tindakan manusia yang menurut si pelaku mengandung makna yang subyektif dan ini meliputi berbagai tindakan nyata,(b) Tindakan nyata dan bersifat membantin sepenuhnya dan bersifat subyektif, (c) Tindakan yang meliputi pengaruh positif dari suatu situasi, tindakan yang sengaja diulang dalam bentuk persetujuan secara diam-diam, (d) Tindakan itu diarahkan kepada seseorang atau kepada beberapa individu, (e) Tindakan itu memperhatikan tindakan orang lain dan terarah kepada orang lain.

Untuk itu, setiap tindakan yang perempuan Bali lakukan dalam menjalani kehidupannya selalu berlandasakan pada hubungan cinta kasih melalui pengapdian, ketulusan, kejujuran, kepatuhan dan pengorbanan yang luar biasa dalam setiap aspek kehidupannya yang tentunya membawa pengaruh keyakinan terhadap tindakannya dan membangun analisisnya tentang faktor-faktor yang mendorong 
munculnya kapitalisme. Dalam hal ini Max Weber melihat ada keterkaitan antara kehidupan penganut calvinisme yang diberi pedoman oleh agama mereka dan jenis perilaku dan sikap yang diperlukan bagi kapitalisme agar bekerja secara efektif. Weber menjelaskan bagaimana calvinis didorong untuk memusatkan diri pada pekerjaan duniawi dan pada saat yang sama juga mewujudkan kehidupan asketis (Sederhana, rajin beribadah, dan hidup hemat). Max Weber berpendapat bahwa penekan pada kreatif dan kerja keras berkombinasi dengan tuntutan agar menjalankan gaya hidu asketis (suatu gaya hidup yang khas bagi agamaagama puritan). Calvinis yakin bahwa mereka tidak akan diberikan ganjaran keselamatan oleh Tuhan kecuali jika mereka sukses dan produktif dalam kehidupan. Oleh karena itu, kehidupan harus didedikasikan kepada efesiensi dan rasionalitas untuk memaksimalkan produktivitas mereka. Salah satunya dengan taat bekerja dan memenets dirinya untuk berbuat baik kepada sesama mahluk hidup. Nilai ekonomi dalam bekerja adalah salah satu yang mempengaruhi paham kapitalisme dalam kehidupan moderen sehingga membuat perempuan Bali mau mendedikasikan hidupnya dalam pencarian nafkah dan mendapatkan keuntungan dalam berusaha dan berdagang di kota Baubau.

Selain tindakan Rasional, analisis kehidupan perempuan Bali dikota Baubau dilihat juga pada tindakan Tradisional sebagai realitas sosial kehidupan perempuan Bali dikota Baubau yang oleh Max Weber menyebutkan tindakan tradisonal adalah bentuk pemahaman dengan perasaan, merupakan pemahaman yang terjadi bila prilaku tersebut bersifat irasional, hal ini diperoleh dengan jalan memproyeksikan diri sendiri kedalam situasi irasional, artinya pemahaman ini didasarkan atas keyakinan bahwa ketaaatan dalam bertindak semata-mata didasarkan atas kepercayaan dari leluhur dan bersifat turun temurun dan sudah dianggap benar serta tidak dipertanyakan lagi sebab akibatnya, kenyakinan ini didasari oleh pemahaman akan pentingnya kepatuhan dalam menjalankan agama dan tradisi yang membawa pada keberkahan hidup dalam menjalankannya.
Salah satu yang mendasari tindakan ini adalah rasa kepatuhan terhadap Tuhan dengan menjalankan semua ajarannya termaksud dengan pengapdian yang tinggi terhadap agama, budaya dan hubungan sosial yang melatar belakangi sifat etos kerja bagi perempuan Bali. Kebiasaan bekerja adalah merupakan perwujudan dari kepercayaannya terhadapnya Tuhan, kepatuhannya dalam menjalani hidup baik dalam keluarga, maupun jalinan sosial bersama maupun terhadap alam semesta adalah merupakan satu bagian dari proses penilaian akan karmanya dalam menjalani hidup. Karena bagi perempuan Bali, kehidupan itu adalah alasan untuk bekerja dan menghindari hukum karmapala. Salah satu bentuknya dengan kepatuhan dalam bertindak yang terkait dengan nilai-nilai kebajikan serta norma yang mengikat tatakelakuannya dalam menjalankan aktivitas.

\section{KESIMPULAN}

Berdasarkan uraian pada bab-bab sebelumnya, maka pada bagian ini akan dikemukakan kesimpulan yang merupakan rangkaian keseluruhan isi dari tesis ini yaitu sebagai berikut :

1. Kemampuan perempuan Bali bekerja pada prinsipnya dilatar belakangi oleh tradisi dan nilai keagamaan, dimana membawa pada pembentukan etos kerja yang melekat pada setiap aspek kehidupan yang melahirkan prinsip-prinsip bekerja dan ketekunan dalam berusaha. Kemandirian, ketangguhan, dan kesabaran adalah bagian dari karekter perempuan Bali yang terbentuk melalui kebisaan bekerja dan kepatuhannya terhadap ajaran agama yang mengajarkan pada penanaman nilai-nilai kebaikan ketika beraktivitas.

2. Peranan perempuan Bali dalam Keluarga selalu dilihat sebagai bentuk kepatuhan dan pengapdian melalui tanggung jawab mengurusi semua kebutuhan keluarga mulai dari pola pendidikan, penanaman nilai agama, sampai pada pencarian nafkah untuk membantu suami. Sehingga alokasi waktu dan beban kerja lebih terlihat pada perempuan Bali dimana mereka 
hampir tidak punya waktu untuk mengurusi kebutuhannya sendiri. Hal inilah yang membawa pada ketimpangan beban kerja mereka yang dilakoni sepanjang hari bahkan sampai akhir hayat dan ini semua dilandasi oleh keyakinan akan kepatuhannya terhadap suami sebagai sosok yang disimbolkan dari perwujudan Dewa yang disucikan, dihormati dan dipatuhi karena akan memberi pengaruh cukup besar pada keyakinan Rengkarnasi (kelahiran kembali) sehingga perempuan Bali tak segan untuk berkorban memenuhi tanggung jawab melayani suami dan keluarganya.

3. Pengaruh keberadaan perempuan Bali di Kota Baubau dilatar belakangi oleh semangat kerja dan sifat terbuka dan mau berbagi ketrampilan bekerja. Konteks etos kerja yang perempuan Bali miliki ternyata membawa pengaruh positif bagi perempuan Buton. Dalam hal ini, kebisaan berprilaku dan bertutur kata halus serta sopan membawa pengaruh yang baik pada perempuan Buton sehingga dalam bergaul ataupun berdagang perempuan Bali tidak pernah sekalipun terlibat pertengkaran atau sekedar cekcok. Hubungan mereka terjalin dengan harmonis sehingga terwujudlah sikap menghargai perbedaan dan karekter masingmasing.

\section{DAFTAR PUSTAKA}

[1] Badan Pusat Statistik Kota Baubau dalam Angka, 2010

[2] Bungin, Burhan. (2003). Analisis Data Penelitian Kualitatif, Pemahaman Filosofi dan Metodologi kearah Pembangunan Model Aplikasi. Jakarta: Penerbit PT Grafindo Persada.

[3] Diknas Kota Bau-Bau, (2013). Bagian Administrasi Pemerintah Umum Kelurahan Ngkari-Ngkari

[4] Horton, B Hunt \& Charles L Hunt. (1984). Sosiologi. Jakarta: Jilid 1, Edisi-6. Penerbit Erlangga.

[5] Moleong, J Lexy. (2007). Metodologi Penelitian Kualitatif. Bandung: Edisi Revisi, Penerbit PT Remaja Rosdakarya

[6] Nehen, Ketut. (1994). Dinamika Masyarakat dan Kebudayaan Bali, Sebuah Ontologi. Denpasar: Cet-1, Penerbit Bali Post.

[7] Ritzer, George. (2010). Sosiologi Ilmu Pengantar [1] Berparadigma Ganda. Jakarta: Penerbit Raja Grafindo Persada

[8] Soekanto, Soerjono. (2002). Mengenal Tujuh Tokoh Sosiologi. Jakarta: Penerbit Raja Grafindo Persada

[9] Soekanto, Soerjono. (1990). Sosiologi Keluarga tentang Ihkwal Keluarga, Remaja dan Anak. Jakarta: Aneka Cipta.
[10] Upe, Ambo. (2010). Transisi Aliran dalam Sosiologi dari Filosofi Positivistik ke Post Positivistik. Jakarta: Cet-1, Penerbit PT. Raja Grafindo Persada

[11] Weber, Marx. (2006). Sosiologi. Yogyakarta: Cet-1, Penerbit Pustaka Pelajar 